\title{
CIVILIZAÇÃO E DESTRUTIVIDADE: UMA LEITURA DOS TEXTOS CULTURAIS DE FREUD*
}

\author{
CIVILIZATION AND DESTRUCTIVITY: A READING OF FREUD’s CULTURAL TEXTS
}

José Oto Konzen, da Universidade Federal do Tocantins

\begin{abstract}
RESUMO
O trabalho investiga a natureza da hostilidade dos indivíduos contra a civilização, tomando por base as interpretações de Freud presentes em textos específicos de sua investigação conhecidos, em geral, por textos culturais. Particularmente, Reflexões para tempos de guerra e morte, de 1915, Psicologia de grupo e análise do ego, de 1921, O futuro de uma ilusão, de 1927, e Mal-estar na civilização, de 1929. A tese central é que essa hostilidade está associada ao caráter repressivo da civilização, que tem por base a idealização cultural, sobre a qual repousa o descompasso existente entre o desenvolvimento técnico e humano e entre o desenvolvimento social e o individual, que demarcam a civilização analisada pelo autor.
\end{abstract}

Palavras chave: Civilização. Hostilidade. Identificação. Sublimação. Idealização.

\section{INTRODUÇÃO}

O objetivo deste trabalho é investigar a natureza da hostilidade dos indivíduos contra a civilização, tomando-se por base as interpretações de Freud presentes em textos específicos de sua investigação conhecidos, em geral, por textos culturais. Particularmente, Reflexões para tempos de guerra e morte, de 1915; Psicologia de grupo e análise do ego, de 1921; O futuro de uma ilusão, de 1927, e Mal-estar na civilização, de 1929. Como evidenciam as datas das publicações, Freud desenvolveu essas análises ao longo da segunda e terceira décadas do século XX. Nesse momento, a burguesia despedia-se do seu período áureo - para usar uma expressão do historiador Hobsbawm - e ingressava num período nebuloso, marcado pelo surgimento da primeira guerra mundial, pelas lutas e revoluções operárias, pela afirmação de movimentos conservadores e totalitários bem como pela emergência de grande crise econômica. A dicotomia entre indivíduo e civilização, que está na base da concepção burguesa, aparece de forma explícita na análise freudiana, que tem por especificidade conferir-lhe uma interpretação psicológica profunda. $\mathrm{O}$ reconhecimento da destrutividade como disposição que integra a civilização, precisamente num momento histórico em que a civilização é exaltada como caminho para a humanização do homem, resulta então na necessidade de explicitar a natureza da própria civilização.

O conceito de civilização assumido por Freud inscreve-se no interior da tradição filosófica moderna, que estabelece um contraponto entre civilização e natureza e concebe a humanização como processo de diferenciação do homem em relação à natureza. Menos

\footnotetext{
* Artigo recebido em 30/06/2009 e aprovado em 03/11/2009.
} 
otimista do que a tradição filosófica e científica oitocentista e novecentista, embora sem abandonar seus objetivos, Freud se ocupa com a explicação dos antagonismos civilizatórios, acolhendo em sua análise as resistências de âmbito individual, manifestas na clínica, e de âmbito coletivo - objeto deste trabalho -, manifestas socialmente pelas massas. Segundo sua interpretação, esses antagonismos estão associados à natureza da própria civilização, que repousa sobre um arranjo específico dos componentes da vida pulsional e as particularidades de seu desenvolvimento histórico. Em sua análise, a civilização deixa de ser fundamentada em um princípio socializador inato, de ordem natural ou racional, e passa a depender da disposição das forças da própria natureza: o instinto de vida e o instinto de morte (o amor e o ódio). Com base nessa concepção, procedimentos puramente racionais e intelectivos serão insuficientes para explicar e ordenar a natureza, e nenhuma instituição social sobreviverá longamente se for baseada apenas em necessidades físicas e, ou, materiais. Com relação à destrutividade, não será mais vista como algo estranho à civilização e passará a constituir uma de suas dimensões fundamentais. De acordo com Freud, é sobre a funcionalização da energia psíquica destrutiva (de morte) e na sua transformação em domínio da natureza externa e interna que repousa o desenvolvimento da civilização. Seu êxito está associado à articulação do princípio destrutivo com o outro princípio, o do amor.

É graças a essa disposição psíquica fundante que a civilização precisa renovar seus esforços em cada indivíduo que nasce e cujo desenvolvimento representa uma atualização do processo civilizatório, razão pela qual é possível estabelecer relações entre o desenvolvimento individual (ontogenético) e o desenvolvimento da espécie (filogenético). Em conformidade com esse princípio, as análises de Freud repousam, de um lado, sobre a biologia e a antropologia cultural e, de outro, sobre observações clínicas. Reconhecem a existência de conquistas civilizatórias relacionadas à reprodução sistemática de determinadas práticas sociais que, pela sua repetição ao longo de gerações, seriam incorporadas e reproduzidas de forma quase instintiva, identificadas, em geral, como inatas. Além dessa assimilação histórica à vida biológica primária, que reconhece a existência de uma evolução na espécie, Freud identifica também a existência de singularidades psicológicas individuais, que não derivam da presentidade do ambiente, mas que são relativas à particularização da herança histórico-biológica, dentre as quais, a presença de maior ou menor hostilidade de um indivíduo comparativamente a outro. Isso faz com que aspectos biológicos e históricos devam ser integrados na análise do desenvolvimento psíquico, sendo o próprio biológico entendido como não absolutamente estático.

Não avançaremos na análise das aproximações existentes entre o desenvolvimento individual e o desenvolvimento da espécie. Sobretudo, porque as análises relacionadas ao desenvolvimento individual derivam de observações clínicas, sistematizadas em textos específicos da obra freudiana. Embora constantemente referido nos textos culturais e assumido como pressuposto teórico, o desenvolvimento individual não é aí desenvolvido, o que traz algumas dificuldades adicionais ao leitor iniciante. Isso nos leva, em alguns momentos, a recorrer a passagens de Totem e tabu, de 1913, Sobre o narcisismo, de 1914, O ego e o id, de 1923, e Além do princípio do prazer, de 1920. 


\section{A CONCEPÇÃO DE CIVILIZAÇÃO E A NATUREZA DA DESTRUTIVIDADE}

Em O futuro de uma ilusão e Mal-estar na civilização, Freud explicita sua concepção de civilização, estabelecendo um contraponto com a vida natural e destacando suas dimensões fundamentais, a saber, a conquista do domínio técnico sobre a natureza (poder sobre as forças externas) e a organização das relações entre os homens (domínio das forças da natureza interna). Segundo sua análise, embora interdependentes, seu desenvolvimento não se constitui em algo necessariamente harmonioso.

A palavra civilização descreve a soma integral das realizações e regulamentos que distinguem nossas vidas das de nossos antepassados animais, e que servem a dois intuitos, a saber: o de proteger os homens contra a natureza e o de ajustar os seus relacionamentos mútuos. (FREUD, 1978a, p.151)

A civilização humana, expressão pela qual quero significar tudo aquilo em que a vida humana se elevou acima de sua condição animal e difere da vida dos animais - e desprezo ter que distinguir entre cultura e civilização - apresenta, como sabemos, dois aspectos ao observador. Por um lado, inclui todo o conhecimento e capacidade que o homem adquiriu com o fim de controlar as forças da natureza e extrair a riqueza desta para a satisfação das necessidades humanas; por outro, inclui todos os regulamentos necessários para ajustar as relações dos homens uns com os outros e, especialmente, a distribuição da riqueza disponível. As duas tendências da civilização não são independentes uma da outra. (FREUD, 1978b, p.88)

Embora Freud não desmereça os condicionantes econômicos e sociais subjacentes às revoltas dos indivíduos contra a civilização, sua perspectiva de análise traz para o centro da discussão os condicionantes psíquicos sobre os quais repousa a emergência do próprio progresso material e a ausência de correspondente em termos de progresso humano. Tratase de compreender a base psíquica subjacente à lógica do desenvolvimento da civilização, que resulta no descompasso existente entre o aprimoramento da capacidade técnica e do desenvolvimento humano. Isso nos leva a buscar identificar a constituição fundamental da civilização, que, segundo a hipótese freudiana, repousa sobre a constituição da unidade social primária: a família.

Freud reporta-se à família primitiva para indicar a formação prototípica do desenvolvimento do psiquismo humano. A passagem da condição natural para a humana ou civilizada é evidenciável no contraponto que se estabelece entre dois momentos distintos. $\mathrm{O}$ primeiro, marcado pela manifestação do poder e do arbítrio de um homem livre sobre a mulher e os filhos, vinculado à realização de seu desejo sexual (objetal). O segundo, constituído pela interiorização da proibição de ocupar o lugar do pai e pela emergência do amor afetuoso entre os irmãos, que dará origem à primeira comunidade humana. Esta perspectiva foi apresentada pela primeira vez em Totem e tabu, onde Freud (1913) oferece uma interpretação psicológica aos resultados das pesquisas antropológicas que marcaram o período ${ }^{1}$, interpretação que ele incorpora em seus textos tardios. Atentemos, pois, para as mudanças psíquicas relacionadas à transformação da família primitiva na passagem da primeira para a segunda geração, tomando por referência a interpretação psicanalítica 
freudiana. Segundo o autor, o ponto de partida das transformações é a fixação do pai no interior da família primitiva.

Quando isto aconteceu, o macho adquiriu um motivo para conservar a fêmea junto de si, ou, em termos mais gerais, seus objetos sexuais, a seu lado, ao passo que a fêmea, não querendo separar-se de seus rebentos indefesos, viu-se obrigada, no interesse deles, a permanecer com o macho mais forte. Na família primitiva, falta ainda uma característica essencial da civilização. A vontade arbitrária de seu chefe, o pai, era irrestrita. (FREUD, 1978a, p. 158)

Na hipótese freudiana, as restrições impostas aos filhos pelo pai todo-poderoso com a finalidade de manter o monopólio sobre as mulheres, originaram o ciúme e o desejo de vingança, associados à insatisfação dos desejos sexuais daqueles. Todavia, do ponto de vista natural, seu poder individual era incapaz de levar a termo sua vingança, o que os levaria a unir-se em busca da realização do seu objetivo, culminando na execução do pai e no seu devoramento coletivo. Essa execução e devoramento, contudo, não teria resultado numa liberação e realização efetiva dos desejos incestuosos, mas numa interiorização da restrição externa, fazendo com que passassem a impô-la a si mesmos, por um ato de vontade. A essa interiorização estariam associadas as restrições civilizatórias fundamentais: a proibição de matar, de prática do incesto e do canibalismo. Em contrapartida, emergiriam relações amorosas inibidas em sua finalidade e convertidas em amizade e amor afetuoso entre os irmãos, dando origem à primeira comunidade humana.

Sobrepujando o pai, os filhos descobriram que uma combinação pode ser mais forte do que um indivíduo isolado. A cultura totêmica baseia-se nas restrições que os filhos tiveram de impor-se mutuamente, a fim de conservar esse novo estado de coisas. Os preceitos do tabu constituíram o primeiro 'direito' ou 'lei'. [...] O primeiro resultado da civilização foi que mesmo um número bastante grande de pessoas podia agora viver reunido numa comunidade. (FREUD, 1978a, p. 159)

A passagem ilustra que a referência analítica de Freud é o modelo de família patriarcal subjacente ao desenvolvimento da civilização européia. Em termos lógicos, na sua condição primária (na primeira geração), a condição da mulher é apresentada como uma condição de desamparo frente às forças naturais, tal qual a dos filhos. A figura do pai, que vem alojar-se no interior da família num determinado momento, constitui uma manifestação do exercício do poder da natureza (do mais forte). Trata-se de uma imposição que acaba favorecendo a manutenção da vida da mulher e dos filhos, ao mesmo tempo em que a restringe aos limites do desejo primário masculino. A natureza impositiva que demarca esta condição não pode resultar numa afirmação estável, porque sua aceitação está vinculada aos limites da natureza, qual seja a falta de uma força capaz de contrapor-se.

Temos, então, de um lado, a condição do pai, que se apresenta como uma condição senhorial, o único livre. O que determina sua fixação no âmbito familiar é o amor sexual (objetal) ${ }^{2}$, cuja afirmação e manutenção impõe-lhe exigências vinculadas ao provimento da subsistência (trabalho) e à defesa contra as ameaças (internas e externas) que se opõem a seu império. De outro lado, a condição da mãe, que se apresenta como uma condição afetiva para com os filhos e de subordinação ao homem. O móbil sobre o qual repousa a 
aceitação de sua condição é duplo: a preservação de sua própria vida e o amor que dispensa a sua prole.

A transformação da condição natural (da primeira geração) para a civilizatória (segunda geração) está vinculada às mudanças fundamentais que ocorrem na esfera do psiquismo masculino. Vejamos como se dá a passagem da transformação do amor sexual (objetal) em amor afetuoso e a substituição do poder-força pelo exercício de um poder regrado e compartilhado entre irmãos. De modo mais problemático, podemos perguntarnos: o que torna possível a aceitação de uma limitação dos impulsos masculinos constituintes da condição natural, isto é, da conquista do objeto sexual (instinto amoroso) e do deferimento da agressividade mortífera (instinto de morte) contra o que impede sua realização?

De acordo com Freud, após terem executado o pai, os irmãos teriam sentido remorso pelo ato cometido. Tal remorso, todavia, não estaria relacionado a uma condição primitiva, onde a exteriorização da agressividade teria sido comum e careceria dessa evidência culposa, como testemunha a condição do pai todo-poderoso. Sua origem estaria associada ao convívio dos filhos com o pai, com o qual passariam a identificar-se. $\mathrm{O}$ processo de convivência com o pai teria feito com que os filhos (irmãos) também desenvolvessem em relação a ele um sentimento de amor e de admiração, fazendo com que se esforçassem para tornar-se iguais a ele, inclusive para assumir a sua condição. A ambigüidade do sentimento dos filhos em relação ao pai emergiria a partir do momento em que a presença deste teria passado a apresentar-se mais como um limite do que como possibilidade de satisfação de seus desejos. Ou seja, quando o exercício de seu poder passou a impedir que os filhos fossem de fato como o pai, que pudessem dispor do objeto do desejo tal qual o pai. Nesse contexto, eles exteriorizariam sua impulsividade destrutiva (mortífera) sobre o pai. Todavia, após a manifestação da agressão, emergeria para o primeiro plano o sentimento de amor e de admiração derivados do processo identificatório na relação estabelecida com o pai. É a esta identificação primária que Freud credita a emergência do remorso e do sentimento de culpa presentes no âmbito do psiquismo humano. O sentimento de culpa, que faz com que o pai morto se apresente como alguém amado, faria com que o ato cometido fosse repudiado, e com ele, os sentimentos que estão na sua origem (a manifestação da agressividade e do amor incestuoso). O que se proíbe, portanto, é a ocupação efetiva do lugar do pai, nas duas dimensões: de possuir as mulheres e de matar a quem o impede.

Embora o acento interpretativo da análise freudiana costume recair sobre a ambigüidade dos sentimentos relacionados à figura paterna, merece destaque também a participação feminina na constituição do psiquismo filial. Nossa hipótese é que a participação feminina esteja vinculada, sobretudo, ao movimento de unificação dos irmãos em busca da realização dos seus desejos, sem o que não teria sido possível o destronamento do pai. Se essa hipótese estiver correta, no processo de convivência entre a mãe e os filhos (irmãos), a base da identificação materna é marcada por um amor "desinteressado", isto é, de natureza não sexual ou objetal, e vinculado ao cuidado exigido para a preservação da vida, de natureza distinta da identificação paterna, que é associada ao desejo de ser forte e dominador. Se a identificação com o amor materno está na base da constituição da comunidade dos irmãos, o que se segue ao ato da execução do pai, a confirmação da vida comunitária, está relacionada à identificação paterna. É nesse sentido que Freud pode dizer 
que o surgimento da civilização repousa sobre o amor, já que é sobre ele que se funda e se confirma a vida da comunidade.

Não é, portanto, o amor do pai pelos filhos que assegura a passagem, mas a relação deles para com o pai, pois, ao tomá-lo como modelo, passaram a esforçar-se para assumir o seu lugar, identificando-se com ele. O que é determinante na recusa da continuidade da matança não é a pura necessidade ou convencimento lógico associado à conservação da vida, já que, como nos adverte Freud, este convencimento racional, por si só, seria impotente para reprimir o instinto destrutivo, como, aliás, fica evidente na primeira geração (e, por extensão, a todo o reino natural). Assim, após a destruição, o que faz os filhos aceitarem a condição da mulher da primeira geração enquanto uma condição que passa a constituir a sua própria é o sentimento de amor e o desejo de continuar sendo amados. De outro lado, a desistência de assumir o lugar do pai e de destruir o que o impede está condicionada à renúncia coletiva. O sentimento de ciúme com relação ao pai, que se converte em sentimento de ciúme contra os irmãos, faz com que a justiça nascente seja fundamentalmente proibitiva. Trata-se de uma exigência de nenhum dos irmãos poder elevar-se à condição do pai. Ninguém pode dispor das mulheres e nem pode matar o que o impede (os irmãos). Assim, a comunidade de irmãos passa a exercer o poder de punição sobre o indivíduo que não respeita as restrições coletivas. Pode-se perceber aí a natureza essencial da hostilidade dos indivíduos contra a civilização. O desejo de destruir o que impede a destruição. Psicologicamente, é aí que reside a revolta contra a civilização.

Trata-se, portanto, de um desejo que não pode ser simplesmente desfeito. Assim, a ambigüidade dos sentimentos com relação ao pai acaba sendo transferida para o interior da civilização, razão pela qual, em princípio, sempre é possível uma emergência do sentimento destrutivo para o primeiro plano. É nisso que reside a possibilidade da regressão. Se a civilização repousa sobre essa ambigüidade fundamental, é preciso então atentar para as formas pelas quais ela é capaz de dispor dessa hostilidade primária em benefício do desenvolvimento civilizatório, já que o instinto não pode ser destruído. No modelo primitivo que expomos, a relativa eficácia da restrição inicial está vinculada à exigência do cumprimento universal (de todos os componentes do grupo) em associação com a experiência do amor afetuoso. Podemos então perguntar-nos: como se dá o avanço da civilização a partir dessa experiência primária familiar em direção à constituição de unidades sociais mais amplas? É possível evitar que essa hostilidade fundante emerja para o primeiro plano, isto é, que não haja um retorno da manifestação da vida pulsional primária?

\section{OS PRINCÍPIOS DA VIDA PULSIONAL E SEU DESTINO NO DESENVOLVIMENTO CIVILIZATÓRIO}

Ao longo do item anterior, reportamo-nos ora à combinação de dois princípios expressos na forma do amor e da necessidade, ora aos princípios da vida pulsional, o instinto de vida (amor) e o instinto de morte (ódio, agressão). Freud de fato trabalha com as duas perspectivas, sobretudo nas obras tardias, pois a existência de um instinto primário de morte foi por ele desenvolvida em Além do princípio de prazer. Nessa obra, na fundamentação deste princípio, ele faz uma aproximação entre argumentos da biologia e observações clínicas. Enquanto, até então, tomava como fundamentos da vida psíquica o princípio do prazer e o princípio da realidade, a partir dessa obra passou a identificar o 
princípio do prazer e o princípio da realidade como vinculados a um mesmo impulso, o da conservação da vida, impulso que passou a denominar "instinto de vida" (amor). A esse impulso primário, que busca aproximar e unir elementos para constituição de unidades vitais cada vez mais amplas e mais complexas, contrapõe um outro, de natureza destrutiva e agressiva, denominado "instinto de morte". Embora antagônicos quando tomados separadamente, conjuntamente eles se revelariam como princípios complementares, de natureza conservadora. No âmbito do psiquismo, o instinto de morte trabalharia pela remoção (anulação) das pressões psíquicas, buscando um estado de equilíbrio que torne a vida suportável. É nesse sentido que, na passagem da natureza para a civilização, ele aparece como um princípio que se dirige contra a manifestação da própria agressividade primária. Ou seja, a interiorização da proibição constitui-se, na verdade, numa forma de fazer com que o princípio da agressão se volte contra ele mesmo, contra sua manifestação direta, o que se daria "mediante a injeção de erotismo" (FREUD, 1996e, p.71). É sobre esta condição que se ergue a civilização. Uma síntese da inovação teórica em foco encontra-se em $O$ ego e o id, onde Freud, ao referir-se a trabalhos anteriores, retoma e reafirma esse antagonismo pulsional. Embora longa, a transcrição que segue justifica-se pela importância que assume nos textos culturais.

Desenvolvi ultimamente uma visão dos instintos que sustentarei aqui e tomarei como base de meus debates ulteriores. Segundo essa visão, temos de distinguir duas classes de instintos, uma das quais, os instintos sexuais ou Eros, é, de longe, a mais conspícua e acessível ao estudo. Ela abrange não apenas o instinto sexual desinibido propriamente dito e os impulsos instintuais de natureza inibida quanto ao objetivo ou sublimada que dele derivam, mas também o instinto autopreservativo, que deve ser atribuído ao ego e que, no início de nosso trabalho analítico, tínhamos boas razões para contrastar com os instintos sexuais. A segunda classe de instintos não foi tão fácil de indicar; ao final, viemos a reconhecer o sadismo como seu representante. Com base em considerações teóricas, apoiadas pela biologia, apresentamos a hipótese de um instinto de morte, cuja tarefa é conduzir a vida orgânica de volta ao estado inanimado; por outro lado, imaginamos que Eros, por ocasionar uma combinação de consequiências cada vez mais amplas das partículas em que a substância viva se acha dispersa, visa a complicar a vida e, ao mesmo tempo, naturalmente, a preservá-la. Agindo dessa maneira, ambos os instintos seriam conservadores no sentido mais estrito da palavra, visto que ambos estariam se esforçando para restabelecer um estado de coisas que foi perturbado pelo surgimento da vida. O surgimento da vida seria, então, a causa da continuação da vida e também, ao mesmo tempo, do esforço no sentido da morte. (FREUD, 1996c, p.53)

Esta concepção está presente no conjunto das análises tardias de Freud. Em Malestar na civilização, sustenta que "em tudo o que se segue, adoto, portanto, o ponto de vista de que a inclinação para a agressão constitui, no homem, uma disposição instintiva original e auto-subsistente, e retorno à opinião de que ela é o maior impedimento à civilização" (FREUD, 1978a, p.175). Em O futuro de uma ilusão, afirma: "acho que se tem de levar em conta o fato de estarem presentes em todos os homens tendências destrutivas e, portanto, anti-sociais e anticulturais, e que, num grande número de pessoas, essas tendências são suficientemente fortes para determinar o comportamento delas na sociedade humana" (FREUD, 1978b, p.88-89). E, em Psicologia de grupo e análise do ego, afirma: "as provas 
da psicanálise demonstram que quase toda a relação emocional íntima entre duas pessoas que perdura por certo tempo - casamento, amizade, as relações entre pais e filhos - contém um sedimento de sentimentos de aversão e hostilidade, o qual só escapa à percepção em conseqüência da repressão". (FREUD, 1996d, p.112)

Retomando o fio condutor de nossa análise, trata-se de verificar a articulação psíquica desses princípios na passagem da natureza para a civilização, ou da primeira para a segunda geração da família primeva. Freud denomina o processo de interiorização das proibições como sendo a formação de um "superego". Trata-se de um processo do desenvolvimento do psiquismo humano que faz com que

a coerção externa se torne gradativamente internalizada, pois um agente mental especial, o superego do homem, a assume e a inclui entre seus mandamentos. (...) Quanto maior é o número (dos que a internalizaram) numa unidade cultural, mais segura é a sua cultura e mais ela pode passar sem medidas externas de coerção. (FREUD, 1978b, p.92)

A formação do superego é um tema central do conjunto das obras tardias do autor. As proibições das práticas do incesto, da morte e do canibalismo constituem restrições de pulsões fundamentais, e é sobre elas que se edifica a civilização. É por se tratar de instintos de natureza profunda, dotados de uma força psíquica de grande intensidade, que em todas as culturas analisadas pelos antropólogos encontraríamos essa evidência proibitiva. Embora a civilização avance em direção à introdução de muitas outras exigências, podemos perceber que, mesmo quanto ao cumprimento destas restrições fundamentais, ela não pode dar-se por satisfeita com suas conquistas, razão pela qual essas proibições constam ainda hoje dentre os ensinamentos morais e as exigências jurídicas. Embora o sentimento de horror que experimentamos frente às práticas do incesto e do canibalismo evidencie um alto grau de internalização da sua proibição, o mesmo não é extensivo à prática do homicídio, com a qual convivemos diariamente, a ponto de não imaginarmos que um dia podermos chegar a sua plena supressão, isto é, ao cumprimento do mandamento que proíbe matar. Podemos perceber então que, de acordo com Freud, os homens não são de fato tão bons quanto imaginamos, porque nos acostumamos a creditar-lhes características socializadoras inatas.

Os homens não são criaturas gentis que desejam ser amadas e que, no máximo, podem defender-se quando atacadas; pelo contrário, são criaturas entre cujos dotes instintivos deve-se levar em conta uma poderosa quota de agressividade. Em resultado disso, o seu próximo é, para eles, não apenas um ajudante potencial ou um objeto sexual, mas também alguém que os tenta a satisfazer sobre ele a sua agressividade, a explorar sua capacidade de trabalho sem compensação, utilizá-lo sexualmente sem o seu consentimento, apoderar-se de suas posses, humilhá-lo, causar-lhe sofrimento, torturá-lo e matá-lo. (FREUD, 1978a, p.167)

Expressando-o de modo sucinto, existem duas características humanas muito difundidas, responsáveis pelo fato de os regulamentos da civilização só poderem ser mantidos através de certo grau de coerção, a saber, que os homens não são espontaneamente amantes do trabalho e que os argumentos não têm valia alguma contra as paixões. (FREUD, 1978b, p.89) 
Vejamos, então, o destino das forças instintivas primárias após o advento da civilização, já que, em princípio, elas não podem ser destruídas, mas tão somente combinadas e transformadas. Dediquemos nossa atenção primeiramente ao destino do instinto de vida (o amor). Como evidenciado no contexto da análise, uma parte da libido (energia amorosa) é convertida em amor afetuoso, sobre o qual repousa a formação de unidades sociais, enquanto outra é integrada ao processo de identificação e convertida em aliado da interiorização da proibição. Uma terceira parte ainda se exterioriza na forma de amor sexual dirigido a um substituto materno (ou paterno, no caso das mulheres), vinculado à constituição do amor conjugal e à reprodução da espécie (FREUD, 1978a, p. 161). O amor (Eros) está, portanto, na origem da formação de unidades sociais cada vez mais amplas, constituintes do processo civilizatório.

Posso agora acrescentar que a civilização constitui um processo a serviço de Eros, cujo propósito é combinar indivíduos humanos isolados, depois famílias e, depois ainda, raças, povos e nações numa única grande unidade, a unidade da humanidade. Porque isso tem de acontecer, não sabemos; o trabalho de Eros é precisamente este. A necessidade, as vantagens do trabalho em comum, por si sós, não as manterão unidas. (FREUD, 1978a, p. 175)

Também o instinto de morte (a agressividade) será convertido em civilização. Uma parte da energia pulsional é dirigida contra a natureza externa, na forma de domínio das forças da natureza (transformação pelo trabalho e pela atividade técnico-científica), enquanto outra é dirigida para um controle interior, isto é, voltada contra o próprio instinto agressivo, com o intuito de evitar que a manifestação pulsional se dê de forma direta e imediata. Outra parte ainda permanece latente em sua forma primária (FREUD, 1923; FREUD, 1978a).

\section{IDENTIFICAÇÃO, IDEALIZAÇÃO E SUBLIMAÇÃO}

Já nos referimos nos tópicos anteriores à importância da "identificação" no processo de constituição do psiquismo humano na passagem da primeira para a segunda geração da família primeva. Num sentido genérico, a identificação tem a ver com a tomada de outro sujeito como modelo a partir do qual se busca conformar seu ser, constituir sua identidade. Segundo Freud, em princípio, trata-se de um processo que se dá de forma simultânea na relação com a mãe e com o pai, como vimos anteriormente. Referindo-se especificamente à identificação dos indivíduos masculinos com o pai, Freud chama atenção para o fato de poder diferenciar-se entre identificar-se com o "ser do pai" ou buscar "ter o pai". No primeiro caso, o laço que se estabelece é com o sujeito. No segundo, com o objeto.

É fácil enunciar numa fórmula a distinção entre a identificação com o pai e a escolha deste como objeto. No primeiro caso, o pai é o que gostaríamos de ser; no segundo, o que gostaríamos de ter, ou seja, a distinção depende de o laço se ligar ao sujeito ou ao objeto do ego. O primeiro tipo de laço, portanto, já é possível antes que qualquer escolha sexual de objeto tenha sido feita. (...) Podemos apenas ver que a identificação esforça-se por moldar o próprio ego de uma pessoa segundo o aspecto daquele que foi tomado como modelo. (FREUD, 1996d, p.116) 
Estamos cientes de que aquilo com que pudemos contribuir para a explicação da estrutura libidinal dos grupos, reconduz à distinção entre o ego e o ideal do ego e à dupla espécie de vínculo que isso possibilita, a identificação e a colocação do objeto no lugar do ideal do ego. (FREUD, 1996d, p.140)

Podemos perceber, nessas passagens, que pode haver um desfecho diferente na relação que se estabelece entre o indivíduo e o objeto que constitui a sua referência. Essa diferenciação é importante, pois aponta para a possibilidade de o indivíduo transcender a sua condição de dependência em relação ao objeto em direção ao qual ele se movimenta, uma transcendência da condição instintiva primária. Atentando à passagem da família primeva para a civilização, percebemos que, se bem sucedida, a identificação resulta no abandono do objeto sexual primário (o amor incestuoso) e da exteriorização da agressividade primária contra o objeto que o impede. Mas, não se limita a essa condição negativa. Ela é também criadora de uma nova realidade: o amor afetuoso e a possibilidade de re-alocação de energia sexual a outro objeto e a afirmação de uma sociabilidade capaz de compartilhar o enfrentamento das forças da natureza pelo trabalho coletivo e pela organização da defesa da vida grupal. Esse movimento de superação da condição instintiva primária é o que Freud concebe como "sublimação".

Se a condição sublimatória se apresenta como uma criação de um novo equilíbrio psíquico, nem sempre é isto que se sucede. Freud estabelece uma diferenciação entre idealização e sublimação, diferenciação que assume uma importância capital para o esclarecimento do descompasso emergente entre o desenvolvimento técnico e o desenvolvimento humano em nossa civilização. Em Sobre o narcisismo, refere que

A sublimação é um processo que diz respeito à libido objetal e consiste no fato de o instinto se dirigir no sentido de uma finalidade diferente e afastada da finalidade de satisfação sexual; nesse processo, a tônica recai na deflexão da sexualidade. [...] A idealização é um processo que diz respeito ao objeto; por ela, esse objeto, sem qualquer alteração em sua natureza, é engrandecido e exaltado na mente do indivíduo. (FREUD, 1996g, p.101)

Essa perspectiva faz com que a superação da condição primária possa ficar a meio caminho. Ou seja, o indivíduo, em razão da singularidade de sua experiência psíquica, pode permanecer vinculado ao objeto sexual primário e pode converter o próprio objeto de identificação em objeto introjetado em seu ego. Nesse caso, instaura-se uma condição em que a sublimação vê-se bloqueada. O tipo neurótico constitui-se pela não aceitação da perda do objeto sexual, o que faz com que a constituição da idealização se processe de forma repressiva, experimentada como imposição. É precisamente pelo fato de não abrir mão da perda do objeto sexual primário que aumenta sua hostilidade contra a restrição civilizatória e, conseqüentemente, sua culpa e sua idealização objetal. Permanece, assim, duplamente vinculado ao objeto sexual e à proibição, incapaz de liberar-se. O resultado é o descompasso entre o ideal que se impõe e a capacidade de sublimar. Manifesta-se, sobretudo, na incapacidade de amar. Trata-se de uma condição marcada pelo sofrimento. É a esta condição que Freud se reporta especialmente em $O$ futuro de uma ilusão (1927), quando evidencia a existência de uma exigência ideal da civilização que contrasta com o nível de desenvolvimento individual efetivo no contexto histórico em que nos encontramos. Na obra Sobre o narcisismo, a condição do neurótico é assim apresentada: 
a formação de um ideal do ego é muitas vezes confundida com a sublimação do instinto, em detrimento de nossa compreensão dos fatos. Um homem que tenha trocado seu narcisismo para abrigar um ideal elevado do ego, nem por isso foi necessariamente bem-sucedido em sublimar seus instintos libidinais. (...) É precisamente nos neuróticos que encontramos as mais acentuadas diferenças de potencial entre o desenvolvimento de seu ideal do ego e a dose de sublimação de seus instintos libidinais primitivos. [...] Como vimos, a formação de um ideal aumenta as exigências do ego, constituindo o fator mais poderoso a favor da repressão; a sublimação é uma saída, uma maneira pela qual essas exigências podem ser atendidas sem envolver repressão. (FREUD, 1996g, p.101)

A idealização assume, portanto, um lugar central na análise freudiana. Como vimos, no grupo familiar primitivo, o despotismo foi substituído pela subordinação comum a uma exigência restritiva e uma parte da energia destrutiva foi canalizada para a luta em prol da conquista da natureza externa. Contra os transgressores, todavia, a manifestação da agressividade primária era liberada e deferida coletivamente, assim como aos indivíduos não pertencentes (exteriores) ao grupo. A manifestação da agressividade primária não era, portanto, inteiramente negada. Ocorre que, na esfera cultural, com o advento do cristianismo, a proibição de matar foi estendida a todo indivíduo (o mandamento "não matarás" é universal), assim como a exigência de amar (deve-se amar até aos inimigos). Qual é o fundamento destas exigências? Elas têm correspondente na realidade? A resposta de Freud é negativa. Trata-se de idealizações que são ilusórias, do âmbito do desejo.

Como vimos até aqui, em sua condição inicial, as restrições e proibições fundamentais limitavam-se aos integrantes do grupo e dela estavam excluídos os elementos externos e o transgressor interno, contra os quais a agressividade primária era deflagrada. Ainda assim, Freud destaca a preocupação evidenciada nesses grupos com relação à possibilidade da extensão da liberação primária para outras situações, evidenciando o medo de regressão. Em Totem e tabu, ele se reporta às restrições impostas aos líderes que retornavam da guerra, dentre as quais, a de tomar as refeições junto aos demais e de ter relações sexuais com as mulheres sem antes passar por um período de purificação (FREUD, 1915, p.305). Com base nessa evidência, ele sustenta que o avanço da civilização em direção à ampliação das restrições morais não deriva de definições éticas ou de decisões racionais, mas da experiência da morte de indivíduos no interior do grupo. A criação das divindades espirituais, segundo evidencia, deriva da presença dos sentimentos ambíguos diante da morte de integrantes do grupo. Ao lado dos sentimentos amorosos de natureza não sexual (afetuosos) compareceriam os sentimentos hostis (agressivos), que seriam projetados para fora, na forma de espíritos (demônios). Freud o concebe como primeira criação teórica da humanidade.

Ao lado do corpo sem vida do ente amado, passou (sic) a existir não só a doutrina da alma, a crença na imortalidade e uma poderosa fonte de sentimento de culpa do homem, mas também os primeiros mandamentos éticos. A primeira e mais importante proibição feita pela consciência que despertava foi: 'Não matarás'. Surgiu em relação a pessoas mortas que eram amadas, como uma reação contra a satisfação do ódio que se ocultava sob o pesar, estendendo-se gradativamente a estranhos que não eram amados e, finalmente, até mesmo aos inimigos. (FREUD, 1996f, p.305) 
Em que se diferencia a criação mitológica inicial, que projeta espíritos (demônios) que ameaçam os homens com sua hostilidade e são temidos por eles em razão do sentimento de culpa, de uma criação religiosa que projeta uma imagem de um deus pai e protetor? A análise de Freud aponta para a existência de um terreno comum na base da criação espiritual, qual seja, o desejo humano. Todavia, enquanto no primeiro caso estaríamos mais próximos da vida pulsinoal primária, no segundo, estaríamos diante de uma "idealização" do objeto.

Segundo o autor, encontramos esta diferenciação na relação libidinosa das massas com seu líder, analisada em Psicologia de grupo e análise do ego, onde, acolhendo a descrião de Le Bun do caráter regressivo do comportamento das massas, propõe-se a oferecer-lhe uma interpreação psicanalítica. Freud acentua a relação com o líder, de que se esperaria "uma impressão de maior força e de mais liberdade de libido". Aqueles que o buscam, em geral, o encontrariam a meio caminho (FREUD, 1996d, p.139). O que estaria em jogo não seria o princípio da realidade, ou seja, a existência real de tais atributos no líder, capazes de realizar seus desejos. Essa condição é evidenciada por Freud no olhar desinteressado do líder em relação às massas, que não seria percebido por elas. Segundo Freud, esta relação com o olhar reflete uma condição primeva, de medo e de terror diante do poder da autoridade do pai. "É precisamente a visão do chefe que é perigosa e insuportável para os povos primitivos, tal como, mais tarde, a da Divindade é para os mortais" (FREUD, 1996d, p.136). Nesse sentido, se a imagem do deus cristão suaviza a relação entre a divindade e os humanos, convertendo-se num deus pai amoroso e protetor, é porque estaria implicada uma idealização da figura do pai. A introjeção da figura paterna no ego e sua elevação à condição de ideal do ego resultariam na ampliação da exigência civilizatória para além do grupo, para o âmbito universal.

Em Reflexões para tempos de guerra e morte, ao referir-se às ilusões que cultivamos com relação à superação da guerra num mundo supostamente desenvolvido técnica e humanamente ou, pelo menos, caso a guerra fosse inevitável, que se poupassem os não combatentes, destaca o descompasso existente entre os princípios ideais universais de nossas nações modernas e sua interiorização efetiva, que se teria evidenciado inclusive entre pessoas mais intelectualizadas. Nesse sentido, ele refere que o realismo dos povos antigos com relação à possibilidade da morte estava mais próximo do que para nós. Ou seja, é por que julgamos que a morte está superada, tomando por base nosso ideal de civilização, que acabamos sendo supreendidos pelo seu retorno. A conclusão de Freud é de que "na realidade, nossos concidadãos não decaíram tanto quanto temíamos porque nunca subiram tanto quanto acreditávamos" (FREUD, 1996f, p.294). Tratava-se de uma ilusão.

As análises freudianas apontam para a existência de aproximações entre a figura do neurótico, a idealização religiosa, que aparece como uma espécie de manifestação de uma neurose coletiva, e a idealização filosófica, que se aproximaria da psicose. O ponto de convergência dessas manifestações individuais e coletivas é a idealização. Se a figura do animal totêmico representou a primeira expressão da projeção da hostilidade humana para fora de si, em seguida substituída pela criação dos espíritos, a criação da religião, que projeta a figura de um pai todo-poderoso, protetor e justiceiro, repousaria sobre a mesma base: a impotência humana diante da natureza e da civilização. Contudo, diante do desenvolvimento científico inerente à civilização, que possibilita um domínio técnico das 
forças da natureza e transforma a própria civilização num poder que ameaça os indivíduos, seria na injustiça da própria civilização que a religião encontraria sua força tardia.

$\mathrm{Na}$ experiência do indivíduo, a neurose manifesta-se na forma de descompasso entre a exigência do ideal e a energia sexual que ele tem disponível para sublimar, do que resulta um distanciamento entre a exigência do ideal e a experiência que ele é capaz de levar a termo. O aumento dessa exigência do ideal provoca então um aumento da hostilidade contra o ideal da civilização, que aumenta a culpa, e com ela, a exigência auto-imposta de conformar-se. Para o conjunto da civilização, isso significaria que os indivíduos sentem-se cada vez mais culposos, na mesma medida em que se identificam com o ideal da civilização. Todavia, ao aumento da culpa corresponde um aumento de compulsão para o trabalho. Esse é o princípio sobre o qual repousa o descompasso existente entre o desenvolvimento do progresso material da civilização e o desenvolvimento humano. A civilização não libera o indivíduo das exigências do trabalho, apesar do progresso resultante que, teoricamente, o possibilitaria, mas converte o próprio progresso em ameaça crescente para o indivíduo. Seu correspondente psíquico é também uma exigência crescente de idealização e de repressão da manifestação da agressividade.

Retornando ao princípio da civilização evidenciado na instauração da família primeva, podemos perceber que a energia pulsional destrutiva fora canalizada para $\mathrm{o}$ trabalho, para a defesa contra os inimigos e, em parte, ficara latente. Assim, a civilização desenvolveu, desde o princípio, uma força contra os inimigos (internos e externos) do grupo. O domínio técnico da natureza, alcançado pela civilização moderna, pode ele próprio ser convertido em forma de destruição. Por isso, com o seu desenvolvimento, aliado ao crescimento da hostilidade dos indivíduos, a civilização passa a investir crescentemente na aplicação de esforços diretamente vinculados à produção de objetos de natureza destrutiva (indústria bélica), capazes de controlar as forças revoltosas dos indivíduos. Podemos perceber, então, que a funcionalização do instinto destrutivo tornou-se extremamente eficaz, sem que houvesse um correspondente desenvolvimento da formação da irmandade humana. A humanidade dos homens, com respeito ao relacionamento intersubjetivo, resulta bastante pobre, graças a natureza do processo civilizatório, marcadamente repressivo. A acumulação que se processa no âmbito do domínio técnico, embora tenha um correspondente no âmbito da idealização, sobre o qual repousa, não encontra correspondente no domínio do desenvolvimento humano.

Estamos, pois, no centro da problemática relacionada à constituição da civilização, que se atualiza através de cada indivíduo, em cujo desenvolvimento psíquico confrontam-se os mesmos princípios da vida pulsional em sua relação com o mundo externo. Essa condição se mantém porque, no âmbito biológico, toda criança depende ainda hoje de um longo cuidado que lhe precisa ser dispensado pelos pais, tal qual nos primórdios da vida humana. Trata-se de uma condição da espécie, que se aplica a todos os indivíduos, independentemente do momento histórico em que se situam. Uma condição vinculada à nossa organização biológica, portanto. É no contexto do desenvolvimento da criança que se inscrevem os processos de identificação e sublimação, cujo desenvolvimento se constitui no que podemos chamar de dimensão histórica e experiência singular, e a cujo amarramento Freud atribui a solução de um complexo psíquico, denominado Complexo de Édipo. Quando bem resolvido, resulta numa condição em que o indivíduo é capaz de sublimar, o que na experiência amorosa significa uma capacidade de viver o amor em profundidade, 
isto é, de operar uma síntese entre o amor sexual e o amor inibido em sua finalidade, constituindo-se numa integridade do ser. Em contraponto a essa integridade, a condição do neurótico aparece como alguém incapaz de reunir num mesmo objeto o desejo sexual e o amor afetuoso, precisamente porque o objeto sexual permanece vinculado a uma manifestação imediata do impulso primário e distante do ideal racional que impõe à sua vida.

\section{CONSIDERAÇÕES FINAIS}

Recuperando o movimento analítico desenvolvido ao longo da exposição, percebemos que a interpretação freudiana permite-nos identificar a existência de uma base repressiva na civilização, sobre a qual repousa o progresso material e a pobreza humana. Freud reconhece que o desenvolvimento da civilização que acumula riquezas através do sacrifício dos indivíduos sem oferecer-lhes uma compensação na esfera distributiva não tem, de fato, condições de atingir uma estabilidade. Não merece ser reproduzida. E tal seria o estado das nações européias de seu tempo. Todavia, o fato desse antagonismo final ter resultado de uma lógica repressiva desloca sua análise para além da conjuntura epocal. De outro lado, reconhece que, embora os indivíduos que se revoltam contra as injustiças próprias das nações européias tenham razões objetivas para lutar, seu movimento interno não encontraria princípio da realidade equivalente para levá-lo a termo. É nesse âmbito que a condição psicológica dos indivíduos se revela como uma condição que ameça a própria civilização. É porque a civilização, que repousa sobre o amor, inviabilizou a constituição de relações afetivas e amorosas; encontra-se ameaçada pelo seu próprio resultado. A reação do indivíduo contra as injustiças tende então a converter-se numa revolta contra o princípio da própria civilização, recorrendo ao exercício da força coletiva em torno da figura de um líder.

Todavia, isso não parece ser um fato novo e estranho à história, já que constitui a sua própria lógica de desenvolvimento. Ou seja, após a regressão, a civilização retoma seu curso, buscando uma compensação da culpa e aumentando as exigências da restrição pulsional e da produção da riqueza coletiva.

É por esta razão que Freud é pouco otimista com relação ao movimento socialista, ainda que reconheça que a organização operária possa ser fundamental para o avanço da distribuição da riqueza. É porque ele não identifica o problema como sendo de ordem fundamentalmente material, mas vinculado ao poder, em sua própria concepção originária, que ele não vê o movimento como algo promissor. O problema freudiano situa a passagem do exercício da autoridade e da disposição da propriedade, os objetos sexuais e materiais, num mesmo processo, evidenciando que o descompasso na acumulação da riqueza e do desenvolvimento humano está vinculado à lógica da civilização. É porque permanecemos relativamente primitivos em termos de humanização que a aposta num reino de convívio fraternal após a divisão da propriedade privada entre a coletividade se revelaria como empreendimento que carece de possibilidade de êxito. Nesse âmbito, a socialização da 
propriedade como solução dos problemas humanos só poderia ser vista como uma forma ilusória, isto é, da ordem do desejo.

A revolta das massas contra a civilização e sua adesão a líderes conservadores aparece como evidência de que eles não conseguem avaliar objetivamente a civilização, precisamente, porque tomam por referência a idealização do ego, que está associada às exigências repressivas da civilização. Imaginam que a condição anterior à civilização era melhor que o estado em que se encontram, tornando-se incapazes de perceber que, nesse estado, de fato ninguém era livre. Ou melhor, apenas um, o mais forte. Entregam-se ao líder, com quem estabelecem uma relação de subordinação irrestrita, não apenas similar ao que lhes é imposto pela civilização, mas em muito superior às exigências reais da mesma. Isto faz com que Freud, sobretudo em Futuro de uma ilusão (1927), após destacar a condição inicial de impotência diante as forças da natureza, o princípio da realidade que se contrapõe ao princípio do prazer, faça uma longa descrição das conquistas da humanidade neste âmbito, identificando-as como conquistas reais. Trata-se de uma chamada de atenção para o fato de o indivíduo que se revolta contra a civilização não ser capaz de fazer este balanço e de identificar a natureza do seu mal-estar, a fim de poder identificar quais repressões precisariam ser mantidas, quais poderiam ser superadas em razão do desenvolvimento histórico e quais elementos negados pela cultura precisariam ser recompostos. Dessa forma, a idealização, que é inerente ao processo civilizatório, não contribuiria para a amenização do mal-estar, porque impediria uma avaliação racional. É nesse âmbito que se justifica a posição racionalista de Freud, que advoga pelo abandono do ideário religioso como princípio da civilização e adere à ciência. Segundo o autor, embora a religião tenha contribuído significativamente com o processo de desenvolvimento civilizatório, não é nela que encontraríamos a possibilidade de lidar com este antagonismo. Em contrapartida, é no procedimento da ciência que Freud encontra esta possibilidade, embora reconheça que tal empreendimento corra o risco de converter-se numa forma de idealização.

As tensões críticas constantes das abordagens culturais que se seguiram à teorização freudiana a partir da segunda metade do século XX, de um modo geral incorporaram as análises do autor com relação ao desenvolvimento da civilização, marcadamente contraditório.

Mark Poster (1979), em Teoria crítica da família, sustenta que a análise freudiana carece de uma teoria social da família, razão pela qual Freud transferiria para o âmbito biológico as tensões históricas existentes entre o indivíduo e a sociedade, sobre as quais repousa a ambigüidade sentimental familiar burguesa. Nesse sentido, confere historicidade a análise freudiana, identificando-a como contribuição importante para a compreensão da particularidade histórica familiar burguesa e destaca que uma teoria crítica da família deveria adotar como ponto de partida o reconhecimento da existência de uma autonomia relativa da instituição familiar em relação ao conjunto social. Sua especificidade é o desenvolvimento da vida emocional, marcada por relações de amor/autoridade enre sexos e idades. Além dessa especificidade, deve atentar também para a organização da vida cotidiana e para as relações que se estabelecem entre família e sociedade mais ampla. A partir destes pressupostos, Poster define quatro modelos de família que estariam na origem da formação da estrutura familiar contemporânea e estabelece como critério de avaliação crítica a democratização das relações entre os sexos e idades. 
No contexto do pós-guerra e diante das novas tendências culturais, diversos autores se defrontaram com o problema da supressão do ideal na cultura, sem que se tenham superado os antagonismos fundamentais. A supressão do ideal na cultura poderia traduzirse também na supressão da possibilidade da crítica e da resistência. Tal perspectiva tem sido apresentada pelo conjunto dos autores da tradição frankfurtiana, apesar das especificidades dos posicionamentos de seus autores. Apenas a título de ilustração, para Marcuse (2001), a polarização entre o superego e o id, entre a razão e a natureza, que perpassa a tradição Ocidental, tem por base o princípio da vida social. A associação entre a razão e a felicidade e o descrédito à vida pulsional, segundo sua análise, remonta à divisão social, onde se separa o reino da liberdade (dos senhores) em relação ao reino da necessidade (mundo da produção material). As reviravoltas que são inerentes à emergência da sociedade burguesa, que resultam na otimização do desenvolvimento material, teriam mantido esta oposição fundamental, estabelecendo, todavia, uma vinculação entre a identificação com um universo abstrato, distante das condições concretas de vida, seja na forma do indivíduo livre, seja na do pertencimento ao coletivo da nação, da raça, etc.. Sob esta perspectiva, ele desenvolve uma teoria da integração como perspectiva de explicação do processo de reprodução social na cultura do pós-guerra. No centro dessa análise, evidencia-se que essa integração resulta numa civilização que não encontra mais a possibilidade de estabelecer um contraponto crítico, razão pela qual Marcuse defende a importância do resgate da teoria enquanto possibilidade de formação de indivíduos capazes de transcender a condição integradora em que se encontram na civilização.

Nesse contexto, a condição psicológica do indivíduo aproxima-se mais da condição que Freud definiu como narcisista, do que da condição do neurótico, vinculada à idealização cultural. Em termos do desenvolvimento psíquico, não se trata de uma reconciliação, mas de uma regressão. $O$ que constitui a condição do narcisista é uma impossibilidade de transcendência, precisamente porque permanece centrado em seu próprio ego. Sob este aspecto, a capacidade de desenvolver um relacionamento amoroso de natureza afetiva vê-se bloqueada. No estágio em que nos encontramos, isso significa que ele tenderá a desenvolver um auto-erotismo que tende a ser preenchido com objetos que lhe são oferecidos pelo ambiente externo. Seu próprio mal-estar na solidão intensifica a compulsão ao consumo. Dessa forma, ele pode autorizar-se a dispensar o convívio social, porque efetivamente não consegue conviver com ninguém. Com isso, aumentam os riscos de regressão social, pois, ao contrário do indivíduo neurótico, que, segundo a psicanálise freudiana, tem cura, o narcisista está impossibilitado de transcendência, porque sua constituição se fixa num estágio psíquico mais primitivo, que não reconhece a instância do outro e que está impossibilitado de sublimar.

\section{ABSTRACT}

The study investigates the nature of people's hostility to civilization, using as a basis Freud's interpretations presented in some of his texts, generally known as cultural texts. His 1915 Reflections on War and Death, his 1921 Group Psychology and the Analysis of the Ego, his 1927 The future of an illusion and his 1929 Civilization and its discontents were analyzed. The central thesis is that this hostility is associated with the repressive nature of civilization, whose basis is the cultural idealization, on which rests the mismatch between the technical and human development and the social and personal development, which characterize the civilization examined by the author. 
Keywords: Civilization. Hostility. Identification. Sublimation. Idealization.

\begin{abstract}
NOTAS
${ }^{1}$ Trata-se de pesquisas desenvolvidas com povos da Austrália e da Milanésia, que revelaram características sócio-culturais bastante distintas do modelo europeu e que foram acolhidas como passado cultural dos próprios europeus. Daí a razão de serem concebidas como culturas primitivas. Essa interpretação é subjacente à concepção evolucionista que marca a tradição cultural européia do final do século XIX, presente na Biologia, na Sociologia, na Filosofia, na Psicologia, etc. e compartilhada também por Freud, pelo menos parcialmente. (FREUD, 1996h)

${ }^{2}$ Importante atentar para o conceito de amor, que pode assumir sentido geral ou mais específico, dependendo do contexto, isto é, como princípio da vida pulsional, ou como manifestação específica deste instinto. "Libido é expressão extraída da teoria das emoções. Damos esse nome à energia, considerada como uma magnitude quantitativa (embora na realidade não seja presentemente mensurável), daqueles instintos que têm a ver com tudo o que pode ser abrangido sob a palavra 'amor'. O núcleo do que queremos significar por amor consiste naturalmente (e é isso que comumente é chamado de amor e que os poetas cantam) no amor sexual, com a união sexual como objetivo. Mas não isolamos disso - que, em qualquer caso, tem sua parte no nome 'amor' -, por um lado, o amor próprio, e, por outro, o amor pelos pais e pelos filhos, a amizade e o amor pela humanidade em geral, bem como a devoção a objetos concretos e a idéias abstratas. Nossa justificativa reside no fato de que a pesquisa psicanalítica nos ensinou que todas essas tendências constituem expressão dos mesmos impulsos instintuais; nas relações entre os sexos, esses impulsos forçam seu caminho no sentido da união sexual, mas, em outras circunstâncias, são desviados desse objetivo ou impedidos de atingi-lo, embora sempre conservem o bastante de sua natureza original para manter reconhecível sua identidade (como em características tais como o anseio de proximidade e o auto-sacrifício).” (FREUD, 1996d, p.101)
\end{abstract}

\title{
REFERÊNCIAS
}

FREUD, S. (1929). Mal-estar na civilização. IN: Freud. São Paulo: Abril Cultural, 1978a, p. 129-194. (Coleção Os pensadores)

(1927). O futuro de uma ilusão. IN: Freud. São Paulo: Abril Cultural, 1978b, p. 85-128. (Coleção Os pensadores)

(1923). O ego e o id. IN: . O ego e o id e outros trabalhos (1923-1925). Rio de Janeiro: Imago, 1996c, p. 15-80. (Coleção Obras Psicológicas Completas de Sigmund Freud, Vol. XIX)

(1921). Psicologia de grupo e análise do ego. IN: . Além do princípio de prazer, psicologia de grupo e outros trabalhos (1920-1922). Rio de Janeiro: Imago, 1996d, p. 79-154. (Coleção Obras Psicológicas Completas de Sigmund Freud, Vol. XVIII)

(1920). Além do princípio do prazer. IN: Além do princípio de prazer, psicologia de grupo e outros trabalhos (1920-1922), p. 13-75. Rio de Janeiro: Imago, 1996e. (Coleção Obras Psicológicas Completas de Sigmund Freud, Vol. XVIII)

(1915). Reflexões para tempos de guerra e morte. IN: A história do movimento psicanalítico, artigos sobre metapsicologia e outros trabalhos (1914-1916). Rio de Janeiro: 
Imago, 1996f, p. 285-312. (Coleção Obras Psicológicas Completas de Sigmund Freud, Vol. XIV)

(1914). Sobre o narcisismo: uma introdução. IN:

A história do movimento psicanalítico, artigos sobre metapsicologia e outros trabalhos (1914-1916) Rio de Janeiro: Imago, 1996g, p. 81-113. (Coleção Obras Psicológicas Completas de Sigmund Freud, Vol. XIV)

(1913). Totem e tabu. IN: Totem e tabu e outros trabalhos (1913-1914). Rio de Janeiro: Imago, 1996h, p. 21-162. (Coleção Obras Psicológicas Completas de Sigmund Freud, Vol. XIII)

HORKHEIMER, M.; ADORNO, T. Temas básicos da sociologia. São Paulo: Cultrix e Editora da USP, s.d.

LE BON, G. Psicologia das multidões. Portugal: Publicações EuropaAmérica Ltda., s.d.

MARCUSE, H. Cultura e psicanálise. 3. ed. São Paulo: Paz e Terra, 2001. (Coleção Leitura)

POSTER, M. Teoria crítica da família. Rio de Janeiro: Zahar, 1979.

José Oto Konzen é professor do Colegiado de Pedagogia do Campus de Miracema da Universidade Federal do Tocantins e doutorando em Educação.

E-mail: joseoto@bol.com.br 